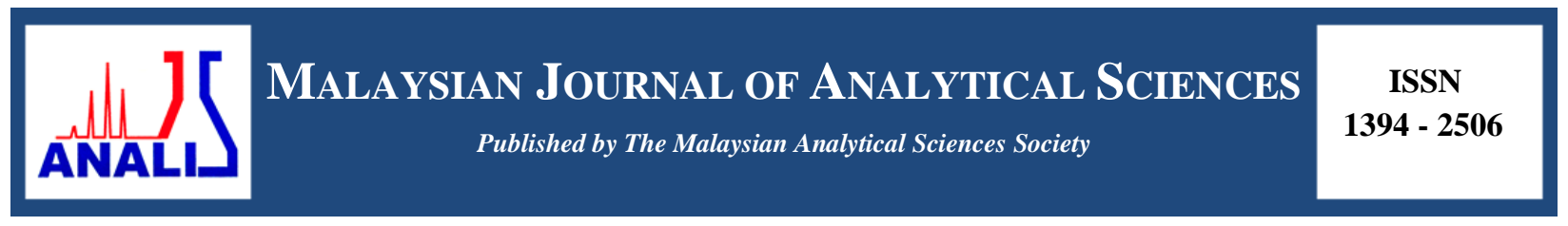

\title{
EFFECT OF GOLD SOLUTION CONCENTRATION ON THE FORMATION AND PHOTOELECTROCHEMICAL PROPERTIES OF GOLD DEPOSITED TITANIUM DIOXIDE NANOTUBES
}

\author{
(Kesan Kepekatan Larutan Emas Terhadap Pembentukan dan Sifat-Sifat Fotoelektrokimia \\ Nanotiub Titanium Dioksida Terendap Emas) \\ Siti Sarah Binti Ismail ${ }^{1}$, Zainiharyati Mohd Zain ${ }^{1}$, Asmaa Kadim Ayal ${ }^{2}$, Lim Ying Chin ${ }^{1}$ * \\ ${ }^{I}$ School of Chemistry and Environment, Faculty of Applied Sciences, \\ Universiti Teknologi MARA, 40450 Shah Alam, Selangor, Malaysia \\ ${ }^{2}$ Department of Chemistry, College of Science for Women, \\ University of Baghdad, Al-Jadriya Campus, Baghdad, Iraq \\ *Corresponding author: limyi613@salam.uitm.edu.my
}

Received: 29 August 2017; Accepted: 20 June 2018

\begin{abstract}
Solar photoelectrochemical (PEC) water splitting for hydrogen production is a clean, eco-friendly, and cost-effective technology that uses solar light as the energy source. Metal oxides, such as $\mathrm{TiO}_{2}$, are preferable as a photoanode in PEC water splitting as they have relatively high reactivity, stable in aqueous solution, and cheaper than non-oxide semiconductors. $\mathrm{However}_{2} \mathrm{TiO}_{2}$ has a large band gap $(3.2 \mathrm{eV})$ that only allows it to be active upon irradiation with UV light. Thus, gold nanoparticles were deposited onto $\mathrm{TiO}_{2}$ nanotubes (TNT) in this study to extend their spectral response to the visible region. Gold deposited titanium dioxide nanotubes (AuTNT) were synthesized by using pulse electrodeposition. Electrodeposition was carried out in $0.5 \mathrm{M} \mathrm{H}_{2} \mathrm{SO}_{4}$ that contained different concentrations $(50,100,500$, and $1,000 \mu \mathrm{M})$ of gold solution, with $75 \%$ duty cycle and an applied potential of $-0.4 \mathrm{~V}$ for 20 minutes in a three-electrode electrochemical cell. The TNTs were annealed at $500{ }^{\circ} \mathrm{C}$ for 2 hours to induce crystallinity prior to gold deposition. The physicochemical properties of the AuTNT were characterised using a Field Emission Scanning Electron Microscope (FESEM), an Energy Dispersive X-ray (EDX), and an X-ray Diffractometer (XRD). Photoelectrochemical properties of AuTNT electrode was evaluated in $0.5 \mathrm{M} \mathrm{Na}_{2} \mathrm{SO}_{4}$ and $2 \mathrm{M} \mathrm{C}_{2} \mathrm{H}_{5} \mathrm{OH}$ under the illumination of a halogen lamp. The AuTNT electrode prepared with $500 \mu \mathrm{M}$ gold solution demonstrated the highest photocurrent compared to other concentrations of gold.
\end{abstract}

Keywords: gold nanoparticles, titanium dioxide nanotube, pulse electrodeposition, photoelectrochemical properties

\begin{abstract}
Abstrak
Pembelahan air secara fotoelektrokimia suria (PEC) untuk menghasilkan hidrogen merupakan teknologi yang bersih, mesra alam, dan kos efektif dengan memanfaatkan cahaya matahari sebagai sumber tenaga. Logam oksida, contohnya $\mathrm{TiO}_{2}$, lebih digemari sebagai fotoanod dalam pembelahan air PEC kerana logam-logam ini mempunyai kereaktifan yang agak tinggi, stabil dalam larutan akueus, dan lebih murah berbanding semikonduktor bukan oksida. Walau bagaimanapun, $\mathrm{TiO}_{2}$ mempunyai jurang jalur yang besar $(3.2 \mathrm{eV})$ yang hanya membolehkan ia berfungsi di bawah sinaran cahaya ultralembayung. Oleh itu, nanopartikel emas diendap ke atas nanotiub $\mathrm{TiO}_{2}$ (TNT) dalam kajian ini untuk mengembangkan tindak balas spektrum TNT ke kawasan cahaya nampak. Nanotiub titanium dioksida yang diendap emas (AuTNT) disintesis menggunakan kaedah nadi elektroendapan. Elektroendapan dilakukan dalam $0.5 \mathrm{M} \mathrm{H}_{2} \mathrm{SO}_{4}$ yang mengandungi kepekatan (50, 100, 500, dan 1,000 $\left.\mu \mathrm{M}\right)$ larutan Au yang berbeza dengan $75 \%$ kitar tugas dan keupayaan dikenakan pada $-0.4 \mathrm{~V}$ selama 20 minit menggunakan sel elektrokimia tiga elektrod. Pemanasan nanotiub titanium dioksida telah dilakukan pada suhu $500{ }^{\circ} \mathrm{C}$ selama 2 jam untuk meningkatkan struktur kristal TNT sebelum pengendapan emas. Sifat-sifat fizikokimia AuTNT dikaji menggunakan mikroskopi pengimbasan elektron
\end{abstract}




\section{Siti Sarah et al: EFFECT OF GOLD SOLUTION CONCENTRATION ON THE FORMATION AND PHOTOELECTROCHEMICAL PROPERTIES OF GOLD DEPOSITED TITANIUM DIOXIDE NANOTUBES}

pancaran medan (FESEM), analisis penyerakan tanaga sinar-X (EDX), dan pembelauan sinar-X (XRD). Sifat-sifat fotoelektrokimia AuTNT telah dinilai dalam 0.5 $\mathrm{M} \mathrm{Na}_{2} \mathrm{SO}_{4}$ dan $2 \mathrm{M} \mathrm{C}_{2} \mathrm{H}_{5} \mathrm{OH}$ di bawah pencahayaan lampu halogen. Elektrod AuTNT yang disediakan dengan kepekatan larutan $\mathrm{Au}$ pada $500 \mu \mathrm{M}$ memberikan fotoarus yang tertinggi berbanding dengan kepekatan emas yang lain.

Kata kunci: nanopartikel emas, nanotiub titanium dioksida , nadi elektroendapan, sifat fotoelektrokimia

\section{Introduction}

Environmental pollution and energy crisis are getting worse day-by-day. Thus, renewable energy sources and environmentally friendly energy conversion methods are studied to overcome these raising issues. Photoelectrochemical (PEC) water splitting process is one of the promising technologies that provide clean and cost-effective energy conversion by exploiting the abundant sunlight irradiating the earth $[1,2]$. The performance of a PEC photoanode can be influenced by the following factors: 1) light absorption efficiency; 2) charge separation; and 3) transport and surface reaction efficiency. An excellent PEC electrode should have the ability to harvest a large portion of the solar energy, is able to support charge separation and rapid transfer to the semiconductor, and have long-term stability [3].

A metal oxide, such as $\mathrm{TiO}_{2}$, is favoured as it is stable in aqueous solutions, non-toxic, low cost, and shows efficient photoelectrocatalysis performance. $\mathrm{TiO}_{2}$ nanotubes exhibit better $\mathrm{PEC}$ performance compared to $\mathrm{TiO}_{2}$ nanoparticles due to their high aspect ratio, light trapping ability, and relatively efficient charge separation [4]. However, pristine $\mathrm{TiO}_{2}$ suffers from a high band gap, reduced efficiency in light harvesting, and poor photogenerated charge carrier separation. Hence, metal/non-metal/noble metal doping is used to reduce the band gap of $\mathrm{TiO}_{2}$ to extend its light absorption range into the visible region and improves the efficiency of the charge carriers [5]. In this study, $\mathrm{TiO}_{2}$ nanotubes were deposited with gold nanoparticles to enhance the performance of PEC into visible light spectra. Gold nanoparticles are capable of increasing the stability of the electrode due to the chemical stability of gold as a noble metal [6]. The gold nanoparticles were deposited onto the nanotube using pulse electrodeposition technique. Subsequently, the effect of different gold solution concentrations on the morphology and PEC performance of the prepared samples were studied.

\section{Materials}

\section{Materials and Methods}

Ti foils $(0.127 \mathrm{~mm}, 99.7 \%$ purity) for producing TNT substrate were purchased from Sigma Aldrich. The Ti foil was cleaned with acetone, isopropanol (R\&M Chemicals), and deionized (DI) water (Millipore Alpha Q system, 18.2 M $\Omega$ ). For the anodization and electrodeposition process, ethylene glycol, $\mathrm{C}_{2} \mathrm{H}_{6} \mathrm{O}_{2}$ (Fisher, 99.8\% p.a.) and ammonium fluoride, $\mathrm{NH}_{4} \mathrm{~F}$ (Fluka, 98.0\%), gold(III) chloride trihydrate, $\mathrm{HAuCl}_{4} \cdot 3 \mathrm{H}_{2} \mathrm{O}$ (Sigma Aldrich, 99.9\%) and sulfuric acid (Fisher) were used without further purification for the preparation of electrolyte.

\section{Preparation of titania nanotubes (TNTs)}

The Ti foils were first cut into $1 \times 2 \mathrm{~cm}$ rectangles and were ultrasonically cleaned with acetone, isopropanol, and DI water for 15 minutes each using an ultrasonicator (Analab Scientific Instruments). Then, the cleaned Ti foils were rinsed with DI water and dried at room temperature. The anodization process was conducted in a standard 2electrode cell, with the Ti foil acting as the anode, while a high-density graphite rod served as the cathode, as shown in Figure 1. The distance between both electrodes was fixed at $2 \mathrm{~cm}$, and the electrodes were immersed in electrolyte that comprised of $95 \%$ ethylene glycol, $5 \%$ DI water, and 0.5 wt. $\% \mathrm{NH}_{4} \mathrm{~F}$. The anodization process was conducted at room temperature with an applied potential of $40 \mathrm{~V}$ for 180 minutes with continuous stirring. Next, the anodized Ti substrate was rinsed with DI water and was ultrasonically cleaned with DI water for another 2 minutes to remove any surface debris. Then, the as-formed TNT substrate was calcined at $500{ }^{\circ} \mathrm{C}$ in a Thermolyne 21100 furnace for 120 minutes, with a heating rate of $2{ }^{\circ} \mathrm{C} / \mathrm{min}$. The calcination step was conducted to induce crystallinity in the $\mathrm{TiO}_{2}$ nanotubes as they were initially amorphous. 


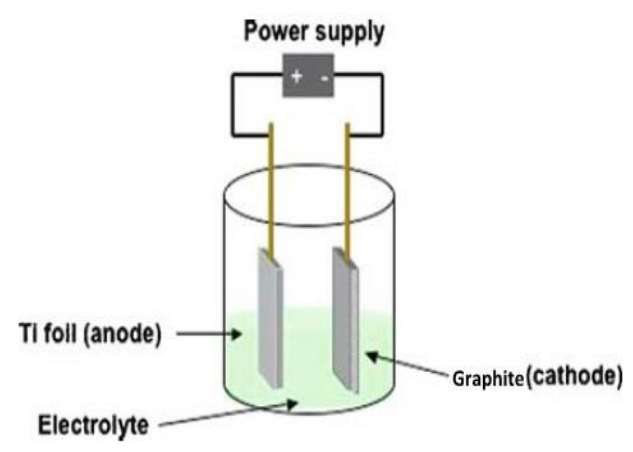

Figure 1. Setup of the anodization of Ti foil

\section{Preparation of gold deposited titania nanotube (AuTNT)}

The prepared TNTs were used as a substrate for the deposition of gold. The gold nanoparticles were deposited onto the calcined TNT using the pulse electrodeposition technique. Cyclic voltammetry was conducted prior to the deposition to determine the potential range for depositing the gold nanoparticles. Different concentrations of gold solution at 50,100,500, and $1,000 \mu \mathrm{M}$ were prepared. Pulse electrodeposition was conducted in $0.5 \mathrm{M}$ sulphuric acid $\left(\mathrm{H}_{2} \mathrm{SO}_{4}\right)$, with various concentrations of gold(III) chloride solution in a three-electrode electrochemical cell. The prepared TNT substrate was used as the working electrode, while a platinum rod was used as the counter electrode and an $\mathrm{Ag} / \mathrm{AgCl}$ as the reference electrode. The deposition was conducted with a fixed duty cycle of $75 \%$ at an applied potential of $-0.4 \mathrm{~V}$ for 20 minutes. Subsequently, the resulting sample was rinsed with DI water and dried in air. Then, it was kept in a desiccator before proceeding with further characterisation.

\section{Photoelectrochemical (PEC) test of gold deposited titania nanotube (AuTNT)}

The PEC performance of the AuTNT was evaluated using a standard three-electrode cell connected to a potentiostat (AUTOLAB). The prepared AuTNT served as the working electrode, while a Pt wire was used as the counter electrode and an $\mathrm{Ag} / \mathrm{AgCl}$ as the reference electrode in a mixed solution of $0.1 \mathrm{M} \mathrm{Na}_{2} \mathrm{SO}_{4}$ and $2 \mathrm{M} \mathrm{C}_{2} \mathrm{H}_{5} \mathrm{OH}$. The cell was irradiated with a $120 \mathrm{~V}, 300 \mathrm{~W}$ halogen lamp, which acted as the visible light source via a quartz window. The irradiation was chopped intermittently at $20 \mathrm{~s}$ intervals to obtain both the dark and photocurrent readings in a single experiment.

\section{Characterisation of AuTNT}

The crystalline structure of AuTNT was determined using X-ray diffraction (XRD, Shimadzu D6000), with Cu $\mathrm{K}_{\mathrm{a}}$ radiation $(\lambda=1.5406 \AA)$, operating at $30 \mathrm{kV}$ and $40 \mathrm{~mA}$. The surface morphology of the AuTNT substrate was studied using the Field Emission Scanning Electron Microscope (FESEM) (Zeiss, SUPRA 40 VP, Germany). Energy dispersive analysis of X-rays (EDX) was performed on Carl Zeiss Field Emission Scanning Microscope attached with Oxford INCA Energy 200 EDX to determine the elemental composition of the AuTNT samples.

\section{Results and Discussion}

Titanium dioxide nanotubes were prepared via electrochemical anodization of titanium in a standard two-electrode system. The oxide formation upon anodization and oxide dissolution by fluoride ions $\left(\mathrm{F}^{-}\right)$would lead to the formation of the self-organised $\mathrm{TiO}_{2}$ nanotubes $[7,8,9]$. $\mathrm{TiO}_{2}$ layer was grown via electric field oxidation and chemical dissolution. The accumulation of electric charges at the interface between $\mathrm{TiO}_{2}$ and $\mathrm{Ti}_{\text {caused }}$ the $\mathrm{Ti}^{4+}$ to disrupt the $\mathrm{TiO}_{2}$ layer, and eventually form nanoporous structures. Subsequently, the thickness of the $\mathrm{TiO}_{2}$ layer would increase due to electric field oxidation [10] and chemical dissolution. The growth of the nanotubes involves the steps shown in equations 1-5:

$$
\begin{aligned}
& \mathrm{Ti} \rightarrow \mathrm{Ti}^{4+}+4 \mathrm{e}^{-} \\
& \mathrm{H}_{2} \mathrm{O} \rightarrow 2 \mathrm{H}^{+}+\mathrm{O}^{2-}
\end{aligned}
$$




$$
\begin{aligned}
& \mathrm{Ti}^{4+}+2 \mathrm{O}^{2-} \rightarrow \mathrm{TiO}_{2} \\
& \mathrm{NH}_{4} \mathrm{~F} \rightarrow \mathrm{NH}_{4}^{+}+\mathrm{F}^{-} \\
& \mathrm{TiO}_{2}+6 \mathrm{~F}^{-}+4 \mathrm{H}^{+} \rightarrow\left[\mathrm{TiF}_{6}\right]^{2-}+2 \mathrm{H}_{2} \mathrm{O}
\end{aligned}
$$

Gold deposited titania nanotubes were prepared via pulsed electrodeposition, with a fixed duty cycle of $75 \%$ and applied potential of $-0.4 \mathrm{~V}$ for 20 minutes. The effect of different Au solution concentrations on the morphology of TNT was determined using a field emission scanning electron microscope (FESEM). Figure 2 shows the morphology of AuTNT substrates prepared in different concentrations of gold solution; 50, 100, 500, and 1,000 $\mu \mathrm{M}$, while bare TNT were used as the control. Based on the figure, the resulting nanotubes have an average diameter of 90-110 nm, and no discernible changes were observed on the size and diameter of the nanotubes upon deposition of Au nanoparticles.

However, upon deposition, the average size of the gold nanoparticles was found to increase with increasing gold solution concentration. The average nanoparticle size at $50 \mu \mathrm{M}$ was $24 \mathrm{~nm}$, at $100 \mu \mathrm{M}$ was $40 \mathrm{~nm}$, at $500 \mu \mathrm{M}$ was $78-95 \mathrm{~nm}$, and at $1,000 \mu \mathrm{M}$, the average nanoparticle size was $100-150 \mathrm{~nm}$. The gold nanoparticles had increased in size because as the concentration of Au increases, the amount of Au nanoparticles had also increased. Thus, more Au nanoparticles were deposited onto TNT nanotubes, which tended to stack up on one another and produced larger sized nanoparticles. Based on Figure 2, small and round gold nanoparticles were obtained at a concentration range between 50 and $100 \mu \mathrm{M}$. It can also be seen that small amounts of gold nanoparticles were randomly distributed on the nanotubes at these concentrations. At 500-1,000 $\mu \mathrm{M}$, bigger sized gold nanoparticles were observed to be deposited onto the nanotubes. Meanwhile, some of the smaller nanoparticles can be seen entering the $\mathrm{TiO}_{2}$ nanotubes. In addition, the gold nanoparticles also appeared to be stacking up on one another, producing a big lump of gold deposit on the surface of the nanotubes. This indicates that gold nanoparticles were present on the TNT. This observation is supported by the EDX analysis, as will be discussed later.

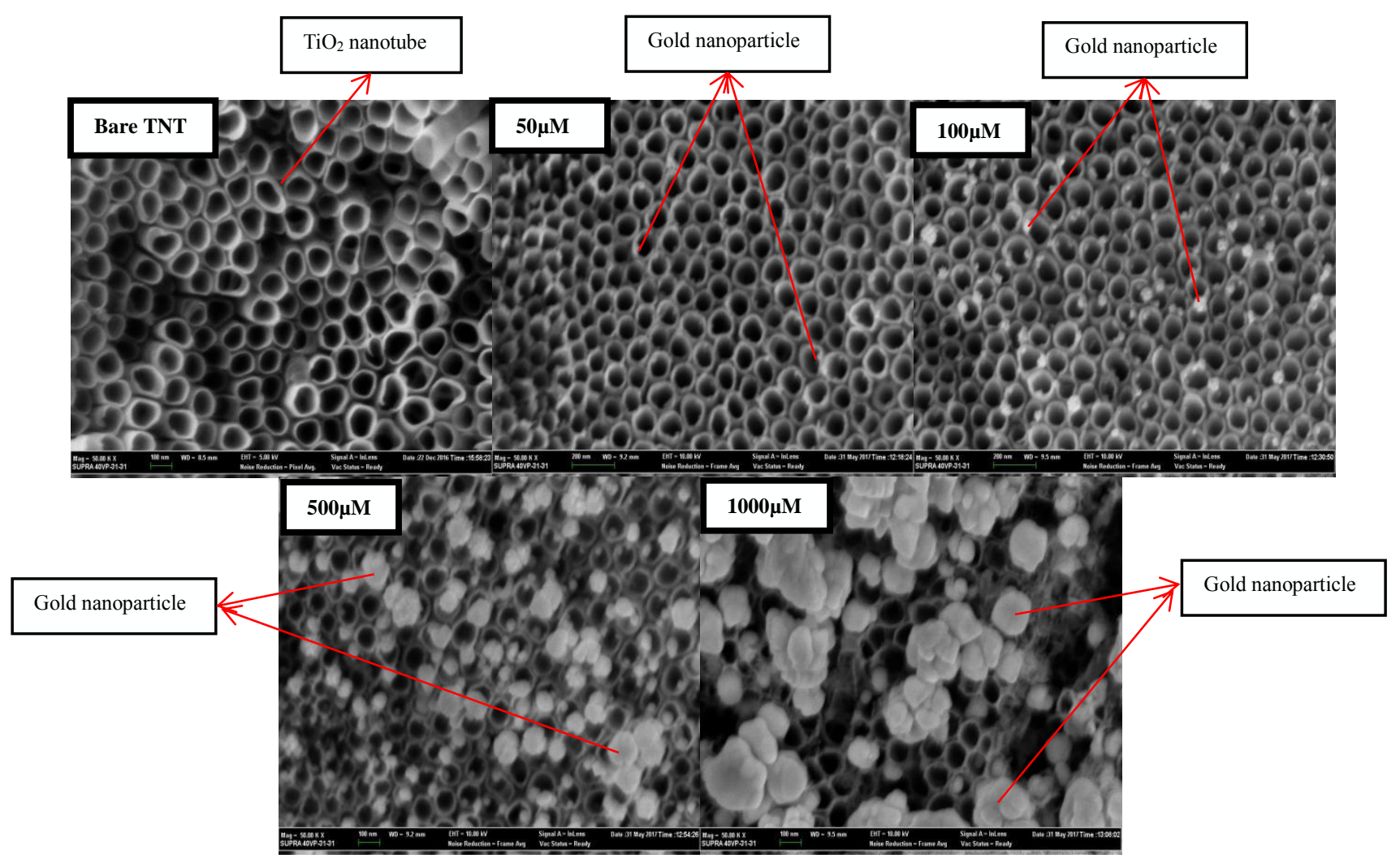

Figure 2. Morphology of AuTNT samples prepared with different concentrations of gold solution 
Table 1 shows the elemental composition of AuTNT samples prepared using different concentrations of Au solution, with a bare TNT substrate as the reference. As expected, the amount of Au nanoparticles had increased with increasing gold solution concentration. From the table, only a small amount of gold nanoparticles was obtained using $50 \mu \mathrm{M}$ and $100 \mu \mathrm{M}$ gold solutions, with atomic percentage of $0.05 \%$ and $0.18 \%$, respectively. At $500 \mu \mathrm{M}$, $3.70 \%$ of $\mathrm{Au}$ was detected, and the highest amount of gold nanoparticles at $31.19 \%$ was obtained using 1,000 $\mu \mathrm{M}$. Higher concentrations of Au had provided more Au particles to be reduced and deposited onto the $\mathrm{TiO}_{2}$ nanotubes. In addition, the presence of titanium and oxygen atoms were also confirmed using EDX. Titanium and oxygen atoms originated from the titanium foils and the nanotubes that formed on the titanium layer. No other impurities were detected for all AuTNT samples.

Table 1. Elemental composition of bare TNT and AuTNT samples

\begin{tabular}{lccccc}
\hline \multirow{2}{*}{ Element } & \multicolumn{5}{c}{ Atomic \% } \\
\cline { 2 - 6 } & Bare TNT & $\mathbf{5 0} \boldsymbol{\mu M}$ & $\mathbf{1 0 0} \boldsymbol{\mu M}$ & $\mathbf{5 0 0} \boldsymbol{\mu M}$ & $\mathbf{1 , 0 0 0} \boldsymbol{\mu M}$ \\
\hline $\mathrm{Ti}$ & 48.67 & 33.46 & 37.47 & 30.43 & 31.38 \\
$\mathrm{O}$ & 56.33 & 66.48 & 62.35 & 65.86 & 37.43 \\
$\mathrm{Au}$ & $\mathrm{ND}$ & 0.05 & 0.8 & 3.70 & 31.19 \\
\hline
\end{tabular}

$\mathrm{ND}$ - not detected

The crystalline structure of the AuTNT was also studied and determined using XRD and the XRD patterns are shown in Figure 3. The XRD patterns are for the bare $\mathrm{TiO}_{2}$ substrate, as-anodized $\mathrm{TiO}_{2}$ substrate, calcined bare $\mathrm{TiO}_{2}$ substrate, and AuTNT samples prepared with various Au concentrations. All substrates showed Ti peaks at $2 \theta=$ $38.5^{\circ}, 35.3^{\circ}, 40.3^{\circ}, 53.2^{\circ}, 70.8^{\circ}, 76.40^{\circ}$, and $82.9^{\circ}$ corresponding to the (100), (002), (101), (102), (103), (112), and (004) planes, respectively (JCPDS 00-044-1294). The bare $\mathrm{TiO}_{2}$ and the as-anodized TNT showed similar XRD patterns, indicating that the as-anodized TNT were amorphous in nature. Upon calcination, anatase peaks at $2 \theta=$ $25.5^{\circ}$ and $48.3^{\circ}$ were observed, which corresponded to the (101) and (200) planes, respectively (JCPDS 00-0211272), as the amorphous TNT began to crystallize. Upon deposition, Au peaks can be observed at $2 \theta=44.6^{\circ}$ and 65.3 $3^{\circ}$, which corresponded to the (111) and (220) planes, respectively (JCPDS 00-004-0784). However, new Au peaks at $2 \theta=44.6^{\circ}$ and $65.3^{\circ}$ were only observed for AuTNT samples synthesised with $500 \mu \mathrm{M}$ and $1,000 \mu \mathrm{M}$ gold solutions. This could be due to the presence of higher amount of gold nanoparticles at higher concentrations compared with at lower concentrations. No peak shift was observed for anatase phase at $2 \theta=25.5^{\circ}$ for all AuTNT samples, revealing that $\mathrm{Au}$ has not been incorporated into the $\mathrm{TiO}_{2}$ lattice.

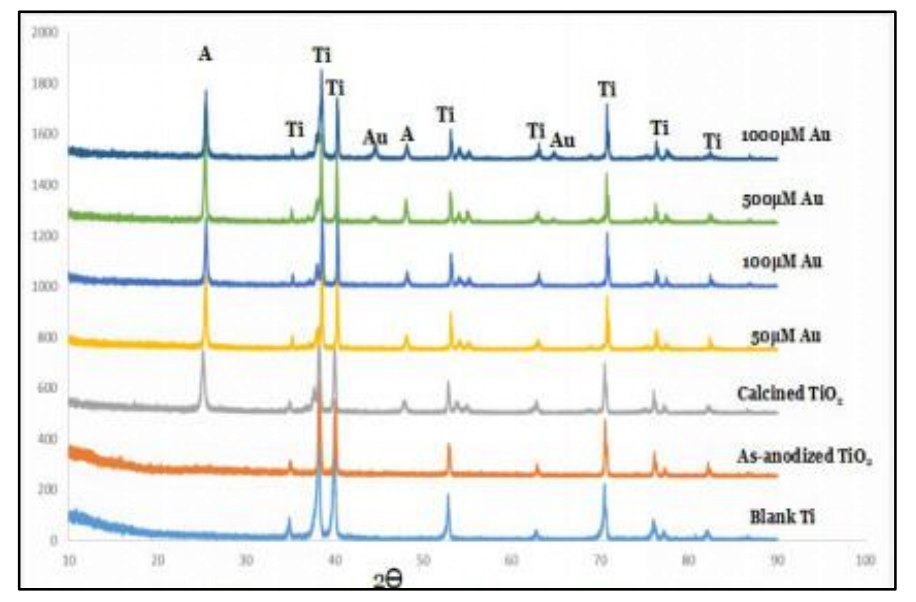

Figure 3. XRD patterns of AuTNT samples with different concentrations of gold solution 


\section{Siti Sarah et al: EFFECT OF GOLD SOLUTION CONCENTRATION ON THE FORMATION AND PHOTOELECTROCHEMICAL PROPERTIES OF GOLD DEPOSITED TITANIUM DIOXIDE NANOTUBES}

The effect of Au deposition on the photoactivity of AuTNT samples was measured using the photoelectrochemical test. In this study, the photocurrent responses were measured under halogen lamp radiation with fixed bias potential. The photoconversion efficiency, $\rceil(\%)$, was measured using equation 6 :

$$
\eta=\frac{I_{o}\left(1.23-V_{\text {bias }}\right)}{J_{\text {light }}}
$$

where $I_{o}$ is the photocurrent density $\left(\mathrm{A} / \mathrm{m}^{2}\right), 1.23 \mathrm{~V}$ is the theoretical potential required for water splitting, $\mathrm{V}_{\text {bias }}$ is the applied external potential (V), and $\mathbf{J}_{\text {light }}$ is the light irradiance $\left(\mathrm{W} / \mathrm{m}^{2}\right)$. The efficiency of the gold deposited titania nanotubes was calculated and recorded in Figure 4. Upon illumination of light, prompt generation of photocurrent can be seen on both bare $\mathrm{TiO}_{2}$ and AuTNT electrodes.

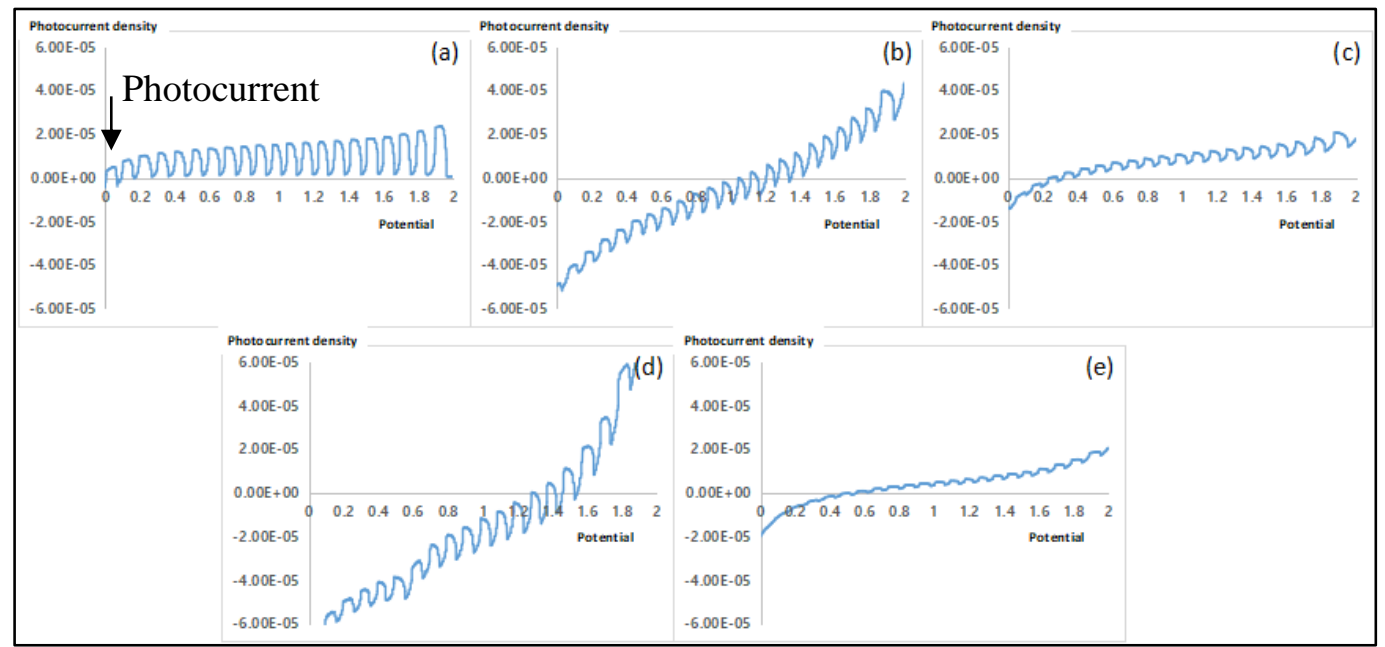

Figure 4. Photocurrent density spectra: (a) bare TNT and AuTNT samples, prepared using different concentrations: (b) $50 \mu \mathrm{M}$, (c) $100 \mu \mathrm{M}$, (d) $500 \mu \mathrm{M}$, and (e) $1,000 \mu \mathrm{M}$ Au solution

Based on Figure 4, upon illumination, a sharp increase of photocurrent can be observed due to the charge generated by the gold nanoparticles. The charge was transferred to the TNT before it reached a steady value and a maximum charge transfer. The current was also seen to drop almost instantaneously when the light was turned off. Upon light illumination, electron-hole pairs were generated by the electric field in the space-charge region between the semiconductor and the electrolyte. This affected the bending of the conduction and valence band edges at the semiconductor surface and promoted the supply of free carriers to the electrode. The gold nanoparticles provided more free charges, which included both electrons and holes that improved the photocurrent of the bare TNT.

$\mathrm{TiO}_{2}$ nanotubes possess the properties of an n-type semiconductor. Figure 4 shows that bare TNT can produce anodic current as an n-type semiconductor. However, upon the deposition of gold nanoparticles on the nanotubes, the prepared AuTNT sample began to produce cathodic current, which began with the anodic current. This observation suggests that the AuTNT sample also possessed the properties of a p-type semiconductor. It also indicates that the AuTNT sample has a combination of the n-type and p-type semiconductor as it was able to produce both anodic and cathodic currents.

The efficiency (П(\%)) of all bare TNT and AuTNT samples were calculated from the PEC results. The highest efficiency was measured for TNT sample deposited with $500 \mu \mathrm{M}$ Au solution at $0.64 \%$ compared with bare TNT at $0.42 \%$, and other concentrations of Au solution. Au nanoparticles could have acted as the active sites that helped to increase the absorption in the visible spectrum. Hence, the photogenerated carrier transfer and separation were enhanced due to the plasmon resonance effect $[8,11]$. Furthermore, the enhanced photocurrent can be attributed to 
the enhanced light absorption and the potential difference generated on the metal-semiconductor interface due to the deposited Au. The potential difference accelerates the separation of the photogenerated hole-electron pairs, resulting in the enhanced photocurrent of the AuTNT sample [12]. However, when the concentration of Au solution was increased to $1,000 \mu \mathrm{M}$, the efficiency had decreased and had even produced a lower efficiency than the bare TNT. This result may be due to the larger sized $\mathrm{Au}$ nanoparticles deposited on the $\mathrm{TiO}_{2}$ nanotubes, which blocked the overall surface of the nanotubes.

\section{Conclusion}

In this study, $500 \mu \mathrm{M}$ Au had resulted in the highest photocurrent efficiency $(\eta \%=0.64)$, which was higher than the efficiency of the bare $\mathrm{TiO}_{2}(\Pi \%=0.42)$. This study has proven that even a small amount of gold nanoparticles would be able to increase and enhance the photocurrent efficiency of titania nanotubes. However, when the concentration of Au was increased, the photocurrent efficiency had decreased and even produced a lower percentage of efficiency compared to the bare TNT. Furthermore, the $\mathrm{pH}$ of Au solution, duty cycle, and deposition duration of gold nanoparticles on titania nanotubes can be varied in the future to obtain a better photocurrent efficiency.

\section{Acknowledgment}

This material is based on a work supported by the Ministry of Higher Education (MOHE) Malaysia through FRGS grant number: 600-RMI/FRGS 5/3 (036/2017). The authors would also like to acknowledge the Faculty of Applied Sciences, Universiti Teknologi MARA (UiTM) for the facilities provided.

\section{References}

1. Chen, Z., Dinh, H. N. and Miller, E. (2013). Photoelectrochemical water splitting. SpringerBriefs in Energy, New York: pp. 49-61.

2. Ampelli, C., Centi, G., Passalacqua, R. and Perathoner, S. (2016). Electrolyte-less design of PEC cells for solar fuels: prospects and open issues in the development of cells and related catalytic electrodes. Catalysis Today, 259: 246-258.

3. Xu, F., Bai, D., Mei, J., Wu, D., Gao, Z., Jiang, K. and Liu, B. (2016). Enhanced photoelectrochemical performance with in-situ $\mathrm{Au}$ modified $\mathrm{TiO}_{2}$ nanorod arrays as photoanode. Journal of Alloys and Compounds, 688: 914-920.

4. Xu, F., Mei, J., Zheng, M., Bai, D., Wu, D., Gao, Z. and Jiang, K. (2017). Au nanoparticles modified branched $\mathrm{TiO}_{2}$ nanorod array arranged with ultrathin nanorods for enhanced photoelectrochemical water splitting. Journal of Alloys and Compounds, 693: 1124-1132.

5. Luo, J., Li, D., Yang, Y., Liu, H., Chen, J. and Wang, H. (2016). Preparation of Au/reduced graphene oxide/hydrogenated $\mathrm{TiO}_{2}$ nanotube arrays ternary composites for visible-light-driven photoelectrochemical water splitting. Journal of Alloys and Compounds, 661: 380-388.

6. Mohite, V. S., Mahadik, M. A., Kumbhar, S. S., Hunge, Y. M., Kim, J. H., Moholkar, A. V. and Bhosale, C. H. (2015). Photoelectrocatalytic degradation of benzoic acid using $\mathrm{Au}$ doped $\mathrm{TiO}_{2}$ thin films. Journal of Photochemistry and Photobiology B: Biology, 142: 204-211.

7. Yin, Y., Liu, E., Li, H., Wan, J., Fan, J., Hu, X. and Pu, C. (2016). Fabrication of plasmonic Au/TiO ${ }_{2}$ nanotube arrays with enhanced photoelectrocatalytic activities. Ceramics International, 42(8): 9387-9395.

8. Notarianni, M., Vernon, K., Chou, A., Aljada, M., Liu, J. and Motta, N. (2014). Plasmonic effect of gold nanoparticles in organic solar cells. Solar Energy, 106: 23-37.

9. Chin, L. Y., Zainal, Z., Khusaimi, Z. and Ismail, S. S. (2016). Electrochemical synthesis of ordered titania nanotubes in mixture of ethylene glycol and glycerol electrolyte. Malaysian Journal of Analytical Sciences, 20(2): 373-381.

10. Nyein, N., Tan, W. K., Kawamura, G., Matsuda, A. and Lockman, Z. (2017). $\mathrm{TiO}_{2}$ nanotube arrays formation in fluoride/ethylene glycol electrolyte containing $\mathrm{LiOH}$ or $\mathrm{KOH}$ as photoanode for dye-sensitized solar cell. Journal of Photochemistry and Photobiology A: Chemistry, 343: 33-39.

11. Pandikumar, A., Lim, S. P., Jayabal, S., Huang, N. M., Lim, H. N. and Ramaraj, R. (2016). Titania@ gold plasmonic nanoarchitectures: An ideal photoanode for dye-sensitized solar cells. Renewable and Sustainable Energy Reviews, 60: 408-420. 
Siti Sarah et al: EFFECT OF GOLD SOLUTION CONCENTRATION ON THE FORMATION AND PHOTOELECTROCHEMICAL PROPERTIES OF GOLD DEPOSITED TITANIUM DIOXIDE NANOTUBES

12. Moakhar, R. S., Masudy-Panah, S., Jalali, M., Goh, G. K. L., Dolati, A., Ghorbani, M. and Riahi-Noori, N. (2016). Sunlight driven photoelectrochemical light-to-electricity conversion of screen-printed surface nanostructured $\mathrm{TiO}_{2}$ decorated with plasmonic Au nanoparticles. Electrochimica Acta, 219: 386-393. 